\title{
Seasonal effect of three pasture plants species on the free-living stages of Haemonchus contortus
}

[Efeito sazonal de três espécies de gramíneas sobre os estágios de vida livre de Haemonchus contortus]

\author{
R.D. Carneiro ${ }^{1}$, A.F.T. Amarante ${ }^{2}$ \\ ${ }^{1}$ Departamento de Agronomia - UNEMAT \\ Caixa Postal 324 \\ 78580-000 - Alta Floresta, MT \\ ${ }^{2}$ Departamento de Parasitologia - IB-UNESP - Botucatu, SP
}

\begin{abstract}
To evaluate both the development and survival of free-living stages of Haemonchus contortus obtained from feces of infected ovine in the four seasons of the year, eggs of this nematode were deposited on three grass species commonly used as sheep pasture in Brazil (Brachiaria decumbens cv. Australian, Cynodon dactylon cv. Coast-cross, and Panicum maximum cv. Aruana). The grasses were cut 5 or $30 \mathrm{~cm}$ height before depositing the feces. Samples of grasses and feces were collected in six sub-plots from each plot one, two, four, eight, 12, and 16 weeks after contamination to determine the recovery of infective $H$. contortus larvae. Most infective larvae were recovered from feces or grass samples deposited on $30 \mathrm{~cm}$ height herbage. High temperature and precipitation levels during the rainy season reduced the infective larvae recovery period from the environment. The best weather conditions for larvae development and survival, in both feces and grasses, were lower temperatures, around $17^{\circ} \mathrm{C}$, in association with low precipitation levels. In general, more larvae were recovered when fecal samples were deposited on Aruana grass.
\end{abstract}

Keywords: sheep, Haemonchus contortus, pasture

\section{RESUMO}

Avaliaram-se o desenvolvimento e a sobrevivência dos estágios de vida livre de Haemonchus contortus em fezes obtidas de ovinos infectados por esse nematódeo, depositadas nas quatro estações do ano, em pastagens de três espécies de gramíneas (Brachiaria decumbens cv Australiana, Cynodon dactylon $c v$. Coast-cross e Panicum maximum cv. Aruana), com duas alturas $(5 \mathrm{~cm}$ e $30 \mathrm{~cm})$ no momento da deposição das fezes. Amostras de fezes e de capim foram coletadas uma, duas, quatro, oito, 12 e 16 semanas após a deposição das fezes e processadas em laboratório, para recuperação de larvas infectantes. $O$ maior número de larvas infectantes foi recuperado das amostras de capim e de fezes nas pastagens com $30 \mathrm{~cm}$ de altura. As condições climáticas que mais favoreceram o desenvolvimento e a sobrevivência das larvas nas fezes, bem como a sobrevivência e a manutenção das larvas no capim foram aquelas com temperaturas médias em torno de $17^{\circ} \mathrm{C}$, acompanhadas de baixas precipitações pluviométricas. As temperaturas mais altas e as precipitações elevadas, que ocorrem na chamada "estação das águas", foram desfavoráveis para a recuperação de larvas infectantes da pastagem. De forma geral, a pastagem de Aruana foi a que possibilitou as maiores recuperações de larvas.

Palavras-chave: ovino, Haemoncus contortus, pastagem

Recebido em 28 de novembro de 2006

Aceito em 14 de maio de 2008

E-mail: carneirodel@ig.com.br 


\section{INTRODUCTION}

In the environment, the type of forage can have considerable impact on both population dynamics and vertical migration of infective larvae of gastrointestinal nematode parasites that infect sheep. As different herbages have distinct growth and morphological characteristics, it is likely that they provide different microclimates on the soil surface that could have a direct effect on larvae development and survival, or indirectly modifying the number of coprophagous or nematophagous organisms (Niezen et al., 1998a). Based on these findings, Niezen et al. (1998a) suggested that selecting a type of forage that is unfavorable for larvae could significantly contribute to parasitism prophylaxis.

Banks et al. (1990) and Barger et al. (1994) found that high temperature and moisture levels in wet tropical climates not only favor egg hatching and larvae development, but also result in high infective larvae mortality rates on the pasture. These authors report that larvae can survive in contaminated tropical pastures for no more than one or two months, and that their populations peak approximately one week after contamination. Because of these peculiarities, gastrointestinal nematode prophylaxis could be achieved when goats were kept on a rotational grazing system involving ten paddocks, remaining 3.5 days on each (Barger et al., 1994). Haemonchus contortus is the most important sheep parasite in Brazil. Detailed studies on the development and survival of the free-living stage of this nematode are essential for the elaboration of a prophylaxis program. This experiment was carried out to evaluate the influence of the microclimate provided by three grass species on the development and survival of free-living stages of $H$. contortus in different periods of the year.

\section{MATERIAL AND METHODS}

The experiment was carried out at the Universidade Estadual Paulista in Botucatu, São Paulo State, Brazil. The experimental area was plain, shadeless, and located in an arenitebasaltic cuesta, at an altitude of approximately $464 \mathrm{~m}$ (Nogueira Júnior, 2000). The climate is classified as Cwa, which means temperate climate (mesothermal) that is rainy in the summer and dry in the winter. The average temperature of the coldest month is below $18^{\circ} \mathrm{C}$, while during the hottest month it is above $22^{\circ} \mathrm{C}$ (Cunha et al., 1999).

The meteorological data were obtained from the same University (UNESP) throughout the study (Fig. 1).

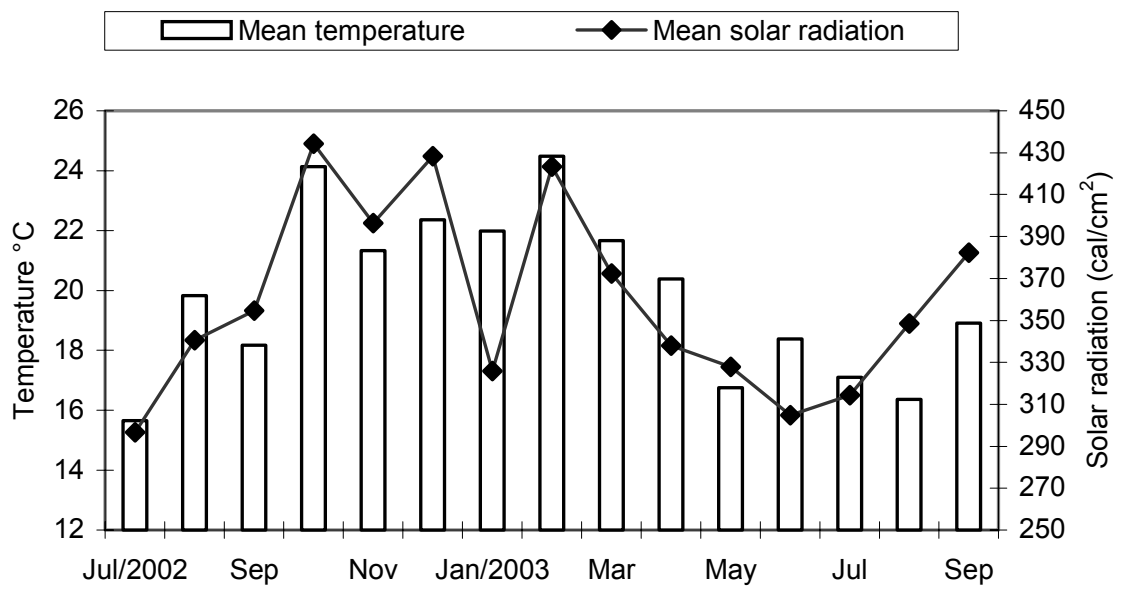

Figure 1. Meteorological data from August 2002 to September 2003, Botucatu, SP, Brazil.

A $144 \mathrm{~m}^{2}$ area was completely fenced-off to keep animals out. Initially, this area was plowed, limed, and fertilized. Six plots $(1.5 \mathrm{~m} \times 12 \mathrm{~m})$ were planted with each of the following grass species: Brachiaria decumbens cv. Australian, Panicum maximum cv. Aruana, and Cynodon dactylon cv. Coast-cross. These grasses species have distinct growth characteristics: Cynodon 
dactylon (Coast-cross) - stoloniferous; Brachiaria decumbens - decumbent; and Panicum maximum cv. Aruana - cespitous (Santos et al., 1999).

Sheep feces containing known amounts of $H$. contortus eggs were deposited four times (winter and spring 2002, and summer and fall 2003) (Tab. 1). One plot with high and another one with low herbage of each grass species were used in each season. The grasses in all plots was cut 5 or $30 \mathrm{~cm}$ above ground level immediately before the feces were deposited, and excess of herbage was removed. The plots were then divided into 36 adjacent sub-plots measuring $30 \times 30 \mathrm{~cm}$ each.

H. contortus was isolated in 2001 from sheep raised on a farm located in Pratânia, São Paulo State. At this farm, $H$. contortus showed resistance to oxfendazole, levamisole, and ivermectin (Amarante et al., 1992).

Two approximately 12-month-old Ile de France rams were used as fecal sample donors in the beginning of the study. They were reared wormfree and given a single dose of $10,000 \mathrm{H}$. contortus infective larvae 30 days before each fecal contamination. Identification of infective larvae produced in fecal cultures confirmed the pure infection of the sheep with $H$. contortus. The sheep were fed with Coast-cross hay and had free access to mineral salt and water. Only the sheep with the highest fecal egg count (FEC) was chosen to be the fecal sample donor for each contamination. Five days before the contamination, feces started being collected in plastic bags that had been attached to the back of the animal. The bags were removed twice a day and stored at $10^{\circ} \mathrm{C}$. On the contamination day, the feces were carefully mixed to avoid breaking the fecal pellets and six sub-samples were taken to determine the mean FEC. The feces were weighed and placed in 221 individual plastic bags with the same sample weight. Six samples were taken from the 221 samples, put in separate Petri dishes and kept in an incubator for seven days at $25^{\circ} \mathrm{C}$ to be used as controls. The larvae were extracted from fecal cultures as recommended by Baermann (1917). The number of infective larvae was estimated in each control culture.

Four contaminations were performed, one in each season of the year. Feces containing $H$. contortus eggs were deposited on pasture and serially recovered. The amount of feces deposited in each sub-plot varied from one season to another depending on animal fecal output, which was smaller in the first contamination. Table 1 summarizes details regarding the weight of the feces that were applied, the number of $H$. contortus eggs per gram of feces (EPG), and the contamination and sampling dates.

Table 1. Dates of contamination, weight of fecal samples (wfs) deposited on each sub-plot, and mean number of $H$. contortus eggs per gram of feces (EPG), mean number of larvae produced in fecal cultures $\left(\mathrm{L}_{3}\right)$, and sampling dates after contamination

\begin{tabular}{cccccccccc}
\hline \multirow{2}{*}{ Contamination } & \multirow{2}{*}{ wfs $(\mathrm{g})$} & \multirow{2}{*}{ EPG } & \multirow{2}{*}{$\mathrm{L}_{3}$} & \multicolumn{5}{c}{ Sampling dates } \\
\cline { 5 - 9 } & & & \multicolumn{1}{c}{ 1* $^{*}$} & $2^{*}$ & $4^{*}$ & $8^{*}$ & $12^{*}$ & $16^{*}$ \\
\hline 7/Aug/02 & 13.5 & 3,500 & 46,212 & Aug 14 & Aug 21 & Sep 4 & Oct 2 & Oct 30 & Nov 27 \\
6/Nov/02 & 20 & 3,200 & 40,240 & Nov 13 & Nov 20 & Dec 4 & Jan 1 & Jan 29 & Feb 26 \\
5/Feb/03 & 20 & 8,540 & 118,048 & Feb 12 & Feb 19 & Mar 5 & Apr 2 & Apr 30 & June 4 \\
14/May/03 & 20 & 1,650 & 8,560 & May 21 & May 28 & Jun 11 & Jul 9 & Aug 6 & Sep 3 \\
\hline
\end{tabular}

*weeks after contamination

The feces were deposited in the middle of the sub-plots. Grasses and feces were collected from six sub-plots (six replicates) one, two, four, eight, 12, and 16 weeks after contamination. The sub-plots from which samples were taken on each date were randomly determined before contamination. The sub-plots were only used and harvested once. Samples were always collected beginning at 7A.M.
The height of the grass in each sub-plot was determined before sample collection. All feces (full and partial pellets) were collected and placed in labeled plastic bags. Grasses were removed by grabbing handfuls of them and cutting it as close as possible to the ground. The collection was made from an area with a $10 \mathrm{~cm}$ radius, as delimited by a metal circle. Based on the results presented by Skinner and Todd Jr. 
(1980), it was assumed that only a few larvae would migrate laterally more than $10 \mathrm{~cm}$. Any grass remaining on soil surface was added to the material. The grasses were placed in other labeled plastic bags.

Infective larvae were extracted from the grasses and from feces using, respectively, the techniques described by Niezen et al. (1998b) and by Baermann (1917). Ensheathed infective $H$. contortus larvae were concentrated in $1.5 \mathrm{ml}$ of water in a graded tube, killed and stained with Lugol's iodine and then counted. Larvae were identified according to the descriptions of Keith (1953).

The numbers of infective larvae recovered from grasses and feces were transformed on $\log _{10}(x+1)$ to stabilize the variance. Significant differences between grasses height and species were figured out through variance analyses using the GLM procedure (User's..., 1990) in a Split-Plot design. The classes in the model were grasses height (low $-5 \mathrm{~cm}$ and high $-30 \mathrm{~cm})$ and grasses species (B. decumbens, $C$. dactylon, and $P$. maximum) and their interactions in the six samplings. Six replicates were made for each type of grass and at each height. Significant differences between the means were determined by Tukey test. $\mathrm{P}<0.05$ was taken to indicate significance. The figures in the results are expressed as arithmetic means of the untransformed values for ease of interpretation.

\section{RESULTS}

The fecal cultures kept under controlled conditions in the laboratory allowed $26 \%$ to $98 \%$ of the eggs to develop to third-stage larvae (L3). There was a low rate of larvae recovery in the environment (compared to the number of deposited eggs), largely below $1 \%$. The highest mean L3 percentages recovered from grass $(0.2 \%$ of the deposited eggs) and feces $(2 \%$ of the deposited eggs) were found when fecal samples were deposited on $30 \mathrm{~cm}$ height Aruana grass in May (28 days and 14 days after contamination, respectively).

Significantly higher overall infective larvae means $(\mathrm{P}<0.05)$ were recovered from grasses or feces when the samples were placed on tall $(30 \mathrm{~cm}$, Fig. 2$)$ rather than on short plants $(5 \mathrm{~cm}$, Fig. 3) in any period of the year.

Except for the May contamination, larvae recovery from feces and grasses was extremely low (even null) after the $8^{\text {th }}$ week of observation (Fig. 2 and 3). The peak of larval recovery from feces occurred during the $1^{\text {st }}$ or $2^{\text {nd }}$ week after contamination; while from grasses, the peak occurred always up to the fourth week after contamination.

There was a significantly higher overall recovery rate of larvae from feces $(\mathrm{P}<0.05)$ after fecal samples were deposited on Panicum than on Brachiaria and Cynodon grasses in August, February, and May. Meanwhile, larval recovery was higher from Coast-cross in November $(\mathrm{P}<0.05)$.

Regarding larvae number recovered from fecal samples after the August contamination, means obtained from samples deposited on Panicum herbage were significantly higher $(\mathrm{P}<0.05)$ than means from Brachiaria, at the $4^{\text {th }}$ week, and from Coast-cross, at the $8^{\text {th }}$ week. After the November contamination, there a was significant difference between means of the three grasses at the $1^{\text {st }}$ week, when the highest mean occurred in Cynodon and the lowest in Panicum. After the February contamination, the means obtained in Panicum herbage at the $1^{\text {st }}$ and $2^{\text {nd }}$ weeks were significantly higher than the means of the other two herbages. After the May contamination, the means obtained for Panicum grasses were significantly higher than the means of the other two grasses at the $1^{\text {st }}$ and $4^{\text {th }}$ weeks.

Significant interactions $(\mathrm{P}<0.05)$ between herbage species $x$ height were recorded at the $4^{\text {th }}$ and $8^{\text {th }}$ week after the August contamination; at the $1^{\text {st }}, 2^{\text {nd }}$ and $4^{\text {th }}$ weeks after the November contamination; at the $1^{\text {st }}$ and $2^{\text {nd }}$ weeks after the February contamination; and at the $2^{\text {nd }}$ and $12^{\text {th }}$ weeks after the May contamination.

Insofar as the influence of grass species on the recovery of larvae from plants is concerned, significantly higher overall means $(\mathrm{P}<0.05)$ were recorded from Aruana after the February and May contaminations. 
A

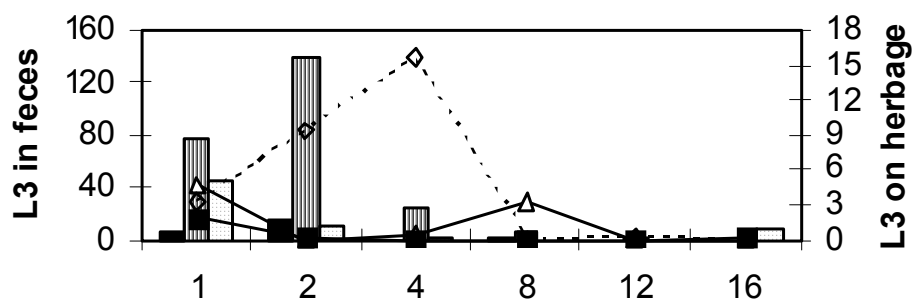

B

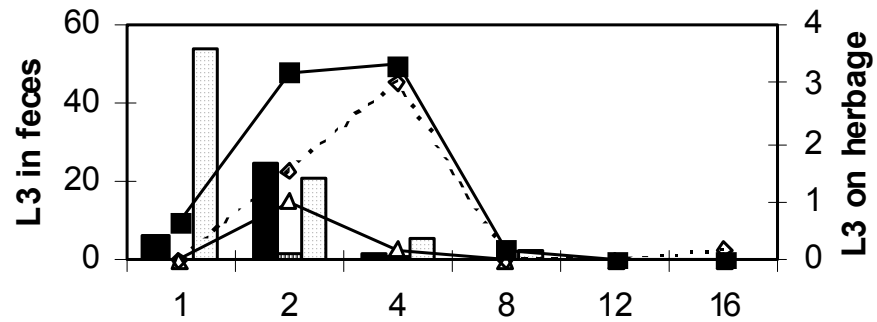

C
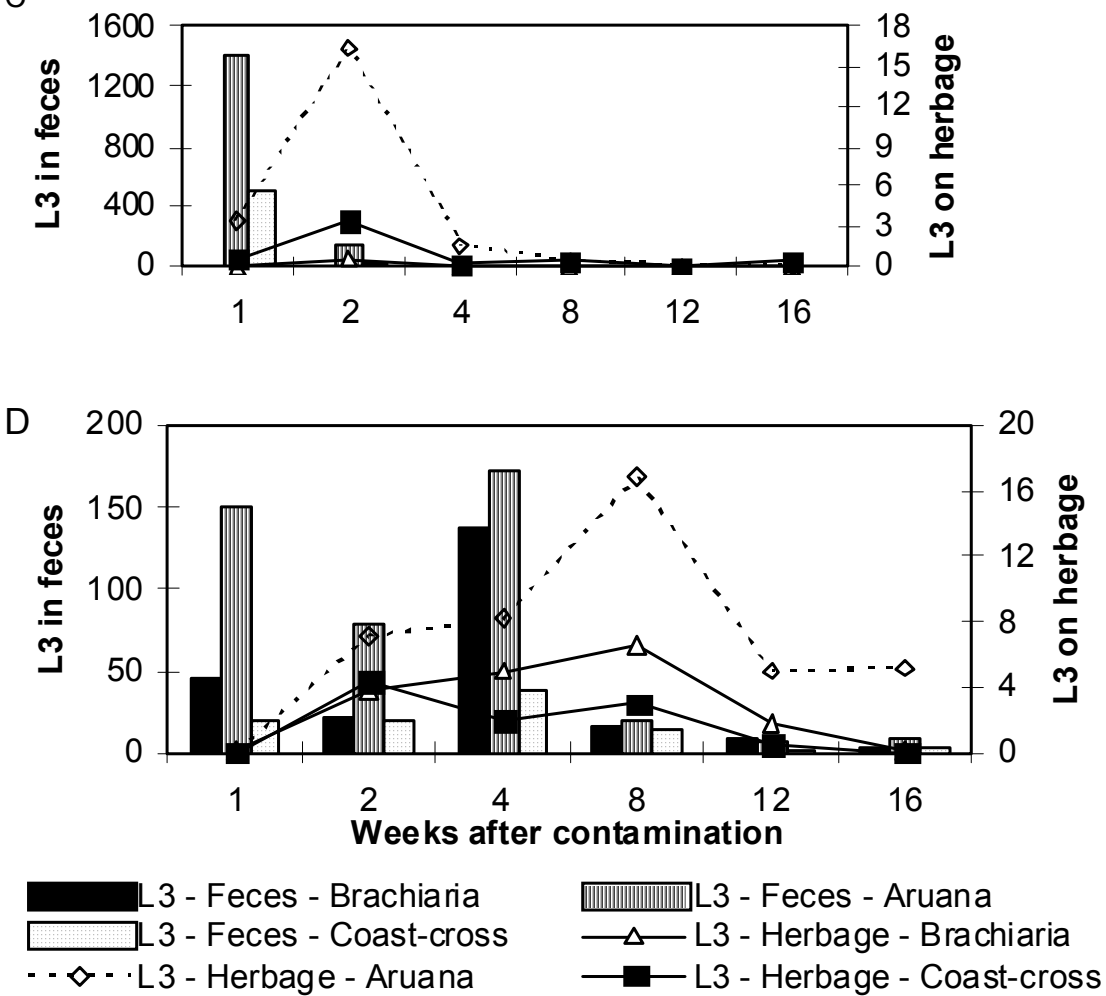

Figure 2. Mean number of $H$. contortus larvae (L3) recovered from feces and herbage after contamination of each sub-plot in August (A); in November (B); February (C); and May (D). Fecal samples were deposited on Brachiaria decumbens, Cynodon dactylon, and Panicum maximum grasses measuring $30 \mathrm{~cm}$ height. 

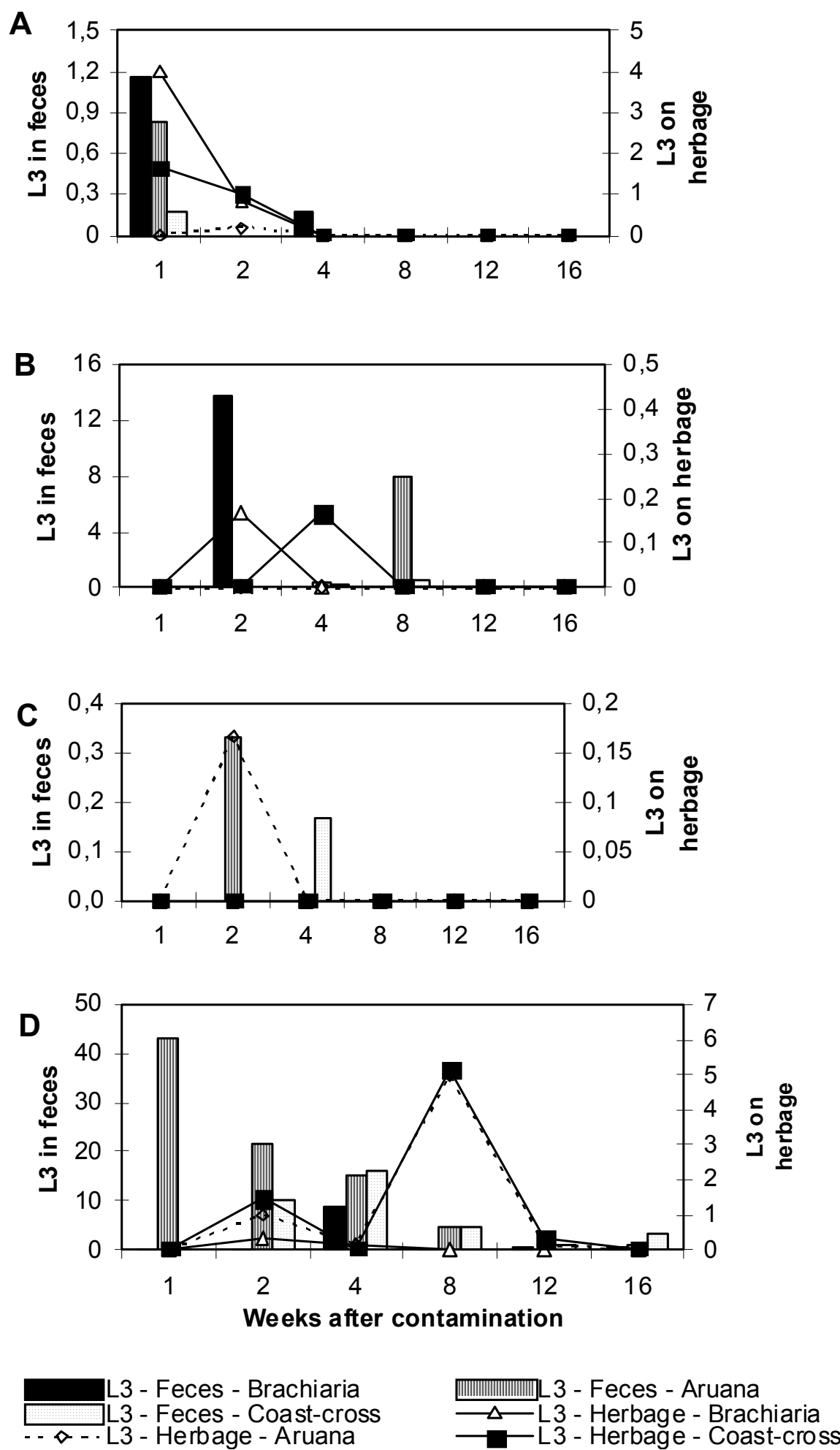

Figure 3. Mean number of $H$. contortus larvae (L3) recovered from feces and herbage after contamination of each sub-plot in August (A); November (B); February (C); and May (D). Fecal samples were deposited on Brachiaria decumbens, Cynodon dactylon, and Panicum maximum grasses measuring $5 \mathrm{~cm}$ height. 
Table 2. Mean height ( \pm standard deviation) of Brachiaria decumbens cv. Australian, Cynodon dactylon cv. Coast-cross and Panicum maximum cv. Aruana grasses 16 weeks after cutting 5 or $30 \mathrm{~cm}$ above the ground level

\begin{tabular}{lcccc}
\multirow{2}{*}{ Month of contamination } & Initial height & \multicolumn{3}{c}{ Grass species } \\
\cline { 3 - 5 } & $(\mathrm{cm})$ & B. decumbens & P. maximum & C. dactylon \\
\hline August & 5 & $66.0 \pm 13.8 \mathrm{a}$ & $63.0 \pm 10.3 \mathrm{ab}$ & $49.3 \pm 3.1 \mathrm{~b}$ \\
November & 30 & $77.5 \pm 7.6 \mathrm{a}$ & $90.7 \pm 9.9 \mathrm{~b}$ & $50.2 \pm 4.9 \mathrm{c}$ \\
& 5 & $84.5 \pm 8.5 \mathrm{a}$ & $73.0 \pm 4.3 \mathrm{~b}$ & $67.5 \pm 4.8 \mathrm{~b}$ \\
February & 30 & $96.8 \pm 8.7 \mathrm{a}$ & $102.0 \pm 13.0 \mathrm{a}$ & $77.3 \pm 4.0 \mathrm{~b}$ \\
& 5 & $87.5 \pm 2.7 \mathrm{a}$ & $49.8 \pm 6.4 \mathrm{~b}$ & $45.0 \pm 4.5 \mathrm{~b}$ \\
May & 30 & $85.5 \pm 4.0 \mathrm{a}$ & $76.0 \pm 4.1 \mathrm{~b}$ & $56.7 \pm 2.3 \mathrm{c}$ \\
& 5 & $15.5 \pm 7.6 \mathrm{a}$ & $21.7 \pm 4.5 \mathrm{a}$ & $21.7 \pm 2.7 \mathrm{a}$ \\
\end{tabular}

Different letters in the rows indicate significant statistical difference by Tukey test $(\mathrm{P}<0.05)$.

Significant differences $(\mathrm{P}<0.05)$ between means were the following: Coast-cross higher than Brachiaria at the $4^{\text {th }}$ week after the November contamination; Aruana higher than Brachiaria at the $4^{\text {th }}$ week after the February contamination; and Aruana higher than Coast-cross at the $4^{\text {th }}$ week and higher than Coast-cross and Brachiaria at the $16^{\text {th }}$ week after the May contamination.

Significant interactions $(\mathrm{P}<0.05)$ between herbage species $\mathrm{x}$ height were recorded at the $2^{\text {nd }}$ week after the August/2002 contamination; at the $4^{\text {th }}$ week after the February/2003 contamination; and at $16^{\text {th }}$ week after the May contamination.

\section{DISCUSSION}

The percentage of recovered larvae compared to the number of eggs deposited was very low, usually below $1 \%$. These results corroborate findings made by Levine and Todd Jr. (1975). According to these authors, more than half of the eggs develop to infective larvae $\left(\mathrm{L}_{3}\right)$ under controlled laboratory conditions, but a very low percentage (only $0.03 \%$ for $H$. contortus) of them produce recoverable larvae on pasture. In New Zealand, after depositing feces with Trichostrongylus colubriformis eggs in $3 \mathrm{~cm}$ height grass, the overall larvae recovery from plants reached $0.9 \%$ of deposited eggs (Niezen et al, 1998b), which is above the $0.2 \%$ found in $30 \mathrm{~cm}$ height Aruana grass, the highest figure recorded in the present experiment.

Larval recovery was much lower when fecal samples were deposited on short grasses $(5 \mathrm{~cm}$ height) than in tall grasses $(30 \mathrm{~cm}$ height), probably because direct solar radiation on the feces caused dryness, destroying eggs and killing larvae. According to Levine and Todd Jr. (1975), direct sunlight kills eggs and larvae relatively fast.

The higher temperature and precipitation levels during the so-called 'rainy season' reduced the infective larvae recovery period from the environment. Meanwhile, the best weather conditions for larvae development and survival, both in feces and grasses, were lower temperatures (around $17^{\circ} \mathrm{C}$ ), associated with low precipitation levels. In the same region, Amarante and Barbosa (1995) also found the highest $H$. contortus grasses contamination from May to October. Similarly, Starke et al. (1992) noticed that buffalo fecal masses deposited on the grasses during the dry season remained a source of infective larvae longer (up to 18 weeks) than in the rainy season (up to seven weeks) in the State of Mato Grosso do Sul. Larval survival was higher in grasses in the dry season (up to 17 weeks) than in the rainy season (up to 11 weeks). Furthermore, all of the fecal masses deposited during the dry season allowed infective larvae development (Starke et al., 1992). In Australia, English (1979) found that $1 \%$ of the nematode larvae of horse parasites survived in feces for up to 20 weeks in fall and winter, but for only four weeks in the summertime. Additionally, in Fiji, Banks et al. (1990) observed that larvae are generally no longer detected nine weeks after herbage contamination from September to March when the temperatures were high, but survival time increases from April to August, when precipitation and temperature levels were low.

In the present research, fecal pellets remained in the environment for several weeks after the 
contamination, regardless of the season. During the dry season, feces played an important role in guaranteeing infective $H$. contortus larvae survival inside the pellets. In Australia, Barger et al. (1984) also showed that infective larvae of cattle parasite can survive for several months in dry fecal masses, during extended drought periods. Different results were obtained in New Zealand, where sheep feces quickly disappeared from the environment in the fall, 10 days after contamination on white clover and ryegrass (Niezen et al., 2003). According to Niezen et al. (2003), earthworms are probably mostly responsible for fecal decomposition in the environment and presumably, to be consumed, feces have to be soft and moist. This explains the long persistence of the feces in the present research, which were usually recovered hard and dry. More detailed studies on sheep fecal degradation under Brazilian conditions are therefore necessary.

According to Barger et al. (1994), under the tropical weather conditions at the Tongatapu Island, in the Pacific Ocean, all nematode eggs hatch and develop quickly and continuously, with a short survival (3-7 weeks) of the resulting infective larvae on the pasture. Under these conditions, it was possible to control goat nematode parasites when the animals were kept in a rotational grazing system consisting of 10 paddocks grazed in sequence for 3.5 days. On the other hand, Levine and Todd Jr. (1975) reported that in Illinois, United States, an expressive number of larvae were still present more than 50 days after pasture contamination, so pasture rotation is not practical to control haemonchosis. It is possible that in the studied environment, a rotational system similar to that described by Barger et al. (1994) can help preventing nematode transmission during the rainy season, but it is unlikely that such system will have any benefit in the dry season, when relatively large numbers of larvae can survive for as long as 16 weeks.

The morphological and biological differences between grasses species produced different microclimates, which, as expected, affected larval development and survival. Generally, the highest numbers of infective larvae were recovered in the microclimate provided by the Aruana grass. The bigger amount of herbage produced by Aruana in the present study probably allowed more shade and moisture, favoring egg and larvae development and survival. Niezen et al. (1998a) also found an influence of the grasses species on larval development success in New Zealand. Numbers of larvae recovered were consistently greater from ryegrass and Yorkshire fog, and lower from chicory, Lucerne, and white clover (Niezen et al., 1998a).

Other studies involving grazing animals in different grasses species should be carried out to determine the most appropriate one and animal management to reach maximum yield and reduce the risks of parasitic gastroenteritis.

\section{REFERENCES}

AMARANTE, A.F.T.; BARBOSA, M.A. Seasonal variations in populations of infective larvae on pasture and nematode faecal egg output in sheep. Vet. Zoot., v.7, p.127-133, 1995.

AMARANTE, A.F.T.; BARBOSA, M.A.; OLIVEIRA, M.A.G. et al. Efeito da administração de oxfendazol, ivermectina e levamisol sobre os exames coproparasitológicos de ovinos. Braz. J. Vet. Res. Anim. Sci., v.29, p.31-38, 1992.

BAERMANN, G. Eine einfache methode zur auffinding von ankylostomum (nematoden) larven in erdproben. Ned. Geneeskd. Tijdschr., v.57, p.131-137, 1917.

BANKS, D.J.D.; SINGH, R.; BARGER, I.A. et al. Development and survival of infective larvae of Haemonchus contortus and Trichostrongylus colubriformis in a tropical environment. Int. J. Parasitol., v.20, p.155-160, 1990.

BARGER, I.A.; LEWIS, R.J.; BROWN, G.F. Survival of infective larvae of nematode parasites of cattle during drought. Vet. Parasitol., v.14, p.143-152, 1984.

BARGER, I.A.; SIALE, K.; BANKS, D.J.D. et al. Rotational grazing for control of gastrointestinal nematodes of goats in a wet tropical environment. Vet. Parasitol., v.53, p.109-116, 1994.

CUNHA, A. R.; KLOSOWSKI, E. S.; GALVANI, E. et al. Classificação climática para o município de Botucatu, SP, segundo Köppen. In: SIMPÓSIO EM ENERGIA NA 
AGRICULTURA, 1., 1999, Botucatu. Anais... Botucatu, 1999. p.487-491.

ENGLISH, A.W. The epidemiology of equine strongylosis in southern Queensland. 1. The bionomics of the free-living stages in feces and on pasture. Aust. Vet. J., v.55, p.299-305, 1979.

KEITH, R.K. The differentiation of infective larvae of some common nematode parasites of cattle. Aust. J. Zool., v.1, p.223-235, 1953.

LEVINE, N.D.; TODD JR., K.S. Micrometeorological factors involved in development and survival of free-living stages of the sheep nematodes Haemonchus contortus and Trichostrongylus colubriformis. A review. Int. J. Biometeorol., v.19, p.174-183, 1975.

NIEZEN, J.H.; CHARLESTON, W.A.G.; HODGSON, J. et al. Effect of plant species on the larvae of gastrointestinal nematodes which parasitize sheep. Int. J. Parasitol., v.28, p.791803, 1998a.

NIEZEN, J.H.; MILLER, C.M.; ROBERTSON, H.A. et al. Effect of topographical aspect and farm system on the population dynamics of Trichostrongylus larvae on a hill pasture. Vet. Parasitol., v.78, p.37-48, 1998b.

NIEZEN, J.H.; ROBERTSON, H.A.; MILLER, C.M. et al. The development of Trichostrongylus colubriformis larvae on a range of herbage species or on plots of differing topographical aspect. Vet. Parasitol., v.113, p.227-240, 2003.

NOGUEIRA JÚNIOR, L.R. Caracterização de solos degradados pela atividade agrícola $e$ alterações biológicas após reflorestamentos com diferentes associações de espécies da Mata Atlântica. 2000. 50f. Dissertação (Mestrado). Escola Superior de Agricultura "Luiz de Queiroz", Universidade de São Paulo, Piracicaba.

SANTOS, L.E.; CUNHA, E.A.; BUENO, M.S. Atualidades na produção ovina em pastagens. In: SIMPÓSIO PAULISTA DE OVINOCULTURA E ENCONTRO INTERNACIONAL DE OVINOCULTURA, 5., Botucatu. Anais... Botucatu, 1999. p.35-50.

SKINNER, W.; TODD JR., K.S. Lateral migration of Haemonchus contortus larvae on pasture. Am. J. Vet. Res., v.41, p.395-398, 1980.

STARKE, W.A.; ZOCOLLER, M.C.; MACHADO, R.Z. et al. Helmintíases em búfalos. II - Sobrevivência de larvas de nematódeos parasitos de búfalos jovens nas fezes depositadas em pastagens no município de Selvíria, MS, nos períodos secos e chuvosos. Rev. Bras. Parasitol. Vet., v.1, p.7-15, 1992.

USER'S guide: statistics (software): version 6. Cary, NC: SAS Institute, 1990. 789p. 